\section{(i) \\ GeORGE Fox \\ UNIVERSITY}

\section{Digital Commons@ George Fox University}

School of Business

Faculty Publications - School of Business

School of Business

2011

\title{
Workplace Learning: Organizations, Ethics, and Issues
}

\author{
Craig E. Johnson \\ George Fox University, cjohnson@georgefox.edu
}

Follow this and additional works at: http://digitalcommons.georgefox.edu/gfsb

Part of the Business Law, Public Responsibility, and Ethics Commons, and the Organizational Behavior and Theory Commons

\section{Recommended Citation}

Johnson, Craig E., "Workplace Learning: Organizations, Ethics, and Issues" (2011). Faculty Publications - School of Business. 88. http://digitalcommons.georgefox.edu/gfsb/88

This Article is brought to you for free and open access by the School of Business at Digital Commons @ George Fox University. It has been accepted for inclusion in Faculty Publications - School of Business by an authorized administrator of Digital Commons @ George Fox University. For more 


\section{Workplace Learning: Organizations, Ethics, and Issues}

The rhetoric surrounding workplace learning is overwhelmingly positive. Boud and Garrick (1999) declare, for example: "Learning at work has become one of the most exciting areas of development in the dual fields of management and education" (p. 1). Advocates promise that education on the job will promote economic prosperity, empower workers, foster collaboration, encourage lifelong learning, and reduce the need for organizational hierarchy (Fenwick, 1998). Government policy makers, human resource professionals, college administrators and faculty, employees, union officials, and executives all support corporate learning. Even the term "workplace learning" has positive connotations. This phrase makes older terms like "vocational education" and "training" appear quaint and outdated.

While supporters of work-related learning are upbeat, some observers offer a more critical perspective. They note that, as with any major international development, there are negative as well as positive consequences, losers as well as winners. Further, contemporary efforts to educate employees generate significant, but often unrecognized, moral dilemmas. These issues call for evaluative (ethical) judgments about whether educational practices are right or wrong.

This chapter draws from the critical perspective to highlight the ethical dimension of workplace learning. Learning situated at work has a potential "shadow side" that must be addressed by educators. The chapter is organized around five ethical issues identified by critics of workplace learning: the power of the economic paradigm, excessive corporate control, corporatism in the traditional university, exploitation of the knowledge worker, and fostering inequalities. Each of these trends threatens significant harm to individuals and/or institutions and organizations. For that reason, the description of each issue includes a critical response designed to counter its negative effects.

\section{The Power of the Economic Paradigm}

As earlier chapters of this Handbook make clear, international economic developments are the primary forces driving workplace learning. In the capitalist global economy, national governments are increasingly focused on staying economically viable. They see knowledge as the key to regional prosperity (Boud and Garrick, 1999; Symes and Mclntyre, 2000). At the same time, the nature of work has shifted from the production of goods to the production of knowledge. Workers in this postindustrial world increasingly labor with their heads, not their hands. Collectively, the skills and knowledge of the workforce are a form of economic capital. Human capital is now seen as the wellspring of economic growth, taking precedence over natural (natural resource based) capital and machine (equipment based) capital (Bouchard, 1998).

Within this economic framework, knowledge is treated as a valuable object or commodity like currency or precious metals (Butler, 2000; Garrick and Clegg, 2000; Myrick, 2004). Commodified knowledge is measurable, observable, recordable information that serves the needs of the organization (Fenwick, 1998). Objectified information is valuable because it serves a useful purpose, like increasing sales, efficiency and productivity. The task of individual learners is to acquire the data, 
skills and competencies, such as formulas, computer programs, accounting procedures, and service routines, that will equip them to help the corporation succeed.

Commodified knowledge can be standardized and offered in many different forms by a variety of providers, ranging from traditional academic units to educational consultants and corporate training departments. Content can be delivered to any location at any hour of the night or day via the Internet. Suppliers often divide up the educational process and assign its components to curriculum developers, trainers, technology specialists and others (Poon, 2006). Quality suffers, however, if curriculum developers and instructors have minimal pedagogical training and the primary objective is to keep training costs to a minimum (Muller et al., 1997).

Critics note that the economic paradigm privileges financial values over other important priorities, like promoting human freedom and social justice. Continuous learning is valued, not because it promotes personal development or reduces economic inequalities, but because it bolsters corporate profitability and regional development (Butler, 2000). When knowledge is treated as a commodity and learners focus on mastering specific skills sets, there is little room for selfreflection that encourages employees to consider their role in the organization and in society (Fenwick, 2001).

Not only does workplace knowledge privilege the needs of the organization over the individual, it may not equip employees to succeed in the contemporary workplace. Predicting which particular skills or knowledge will be needed in a rapidly changing global environment is difficult. Those with narrow training may be preparing themselves for jobs that will no longer exist. Consider how, for example, computer programming was once considered an essential skill for everyone, and even school children learned Fortran and other programming languages (Bouchard, 1998).

\section{Critical Response}

Economic concerns will always play an important role in workplace learning, but they don't have to be the only or the most significant values. The international movement toward corporate social responsibility is a case in point. Socially responsible companies typically have values that extend beyond profit. The guiding principles of Starbucks, for example, include treating others with respect and dignity, embracing diversity, and contributing positively to communities and the environment (Starbucks, 2008). If Starbucks and other multinational companies hope to act as responsible members of the global community, their educational efforts will have to promote noneconomic priorities. Employees will need to learn about the environment, diversity, poverty, and other issues, and develop strategies for addressing these challenges.

Workplace learning's narrow focus on skills and competencies runs contrary to a longstanding tradition in vocational education in the United States. The earliest union education movements equipped members with critical skills to analyze class and social differences (Aronowitz, 1990; Taylor, 2007). Educational pioneer John Dewey (1916) argued that employees should learn about history, science, economics, civics and politics to help them deal with social problems.

An education which acknowledges the full intellectual and social meaning of a vocation would include instruction in the historic background of present conditions, training in science to give intelligence and initiative in dealing with 
material and agencies of production, and study of economics, civics, and politics, to bring the future worker into touch with the problems of the day and the various methods proposed of its improvement (p. 318).

Dewey's vision promoted the creation of workplaces that value their employees and foster community. He wanted to empower workers to become active citizens who would transform businesses and other social institutions into functioning democracies. In contrast, the emphasis of modern workplace learning is on creating efficient, compliant workers (Butler, 2000).

Education for the whole person, such as that advocated by Dewey, appears to be better preparation for the demands of the modern workplace because it fosters critical thinking, analytical skills, creativity, and self-mastery (Mantsios, 1990; Caldwell, 2000). "Liberal" education has a long history in the academy. Training in the liberal arts is designed to better the life of learners; the subject matter may or may not have immediate application. However, through the study of the liberal arts, learners develop problem solving, self-reflective, and strategic thinking skills that can be applied in many different settings (Useem, 1989; Brown, 1994; Houston, 1996). Management guru Peter Drucker (2001) argued that the practice of management is a liberal art because managers utilize knowledge, wisdom, self-understanding and leadership to solve realworld problems.

\section{Excessive Corporate Control}

Corporate control over work-related learning appears to be a given. After all, companies fund training programs and learning generally takes place in the workplace setting. Nonetheless, critics note that such control, particularly if it remains entirely in the hands of management, can have undesirable consequences. Training generally reinforces the organizational power structure rather than contesting it (Fenwick, 2001). Few organizations are willing to sponsor workshops that encourage workers to criticize excessive executive pay or to take issue with unfair promotion policies, for instance.

The development of corporate universities further extends management control over knowledge. Corporate universities bring together development and education functions under a "strategic umbrella" (Meister, 1998, p. 29). Such functions include formal classes and on-the-job training, leadership development, mentoring, career planning, professional certification, and e-learning (Hundley, 2002). Corporate universities are designed to further the goals of the organization by: (1) developing core competencies; (2) transmitting the group's culture; (3) promoting the corporate mission and vision; (4) recruiting members for organizational initiatives; (5) assigning learners to work on company projects; and (6) cutting product development times (Prince and Beaver, 2001; Jarvis, 2001; Hundley, 2002).

Workplace learning has also given short shrift to union input. Unions, despite shrinking membership and influence in some industrialized nations, remain "the most important and popular form of worker (or working class) organization in most liberal democracies" (Spencer, 2002, p. 11). In recent years, governments in Europe, Britain, Australia, and elsewhere have encouraged management and labor to form educational partnerships to promote economic development (Sutherland and Rainbird, 1999; Forrester, 2002a). While such partnerships can promote individual development, they are dominated by 
management and give priority to organizational development over the personal development of union members. Employers may fear that providing employees with transferable skills will increase turnover or that newly empowered workers will be hard to manage. Those workers who refuse to participate in training and development programs risk being punished. Participants may find that the greater job flexibility promised by workplace learning translates instead into greater job responsibilities requiring more intense effort on their part (Heyes, 1999; Sutherland and Rainbird, 1999).

\section{Critical Response}

The promise of workplace learning cannot be realized unless employees are empowered to direct their learning. Workers need to be involved in program and course development, delivery, and evaluation. Unions and other employee organizations ought to function as true partners with management in collaborative educational efforts.

Critical (emancipatory, transformative) pedagogy is one strategy for providing learners with more control over their on-thejob education. Such pedagogy empowers employees to become equal partners in their organizations and to make their corporations more democratic. Gregson (1994) notes that critical pedagogy is marked by four values. First, it is participatory, involving students in collaborative group learning experiences. Working in diverse groups highlights the importance of collective learning and fosters responsibility for oneself and other team members. Further, such experiences diminish stereotypes of those of different backgrounds, enable participants to learn at their own pace, encourage significant encounters between group members, and help students develop communication and problem-solving skills that transfer to other settings.

Second, critical pedagogy takes learners from the known to the larger context. Students begin by learning job-related skills and information but then go on to examine how technology, knowledge, and work skills relate to the organization and society. Participants are also introduced to the historical setting. They explore such topics as the development of a product or industry and conflicts between management and labor.

Third, critical pedagogy engages participants in liberatory dialogue. They become equal partners in the learning process; the instructor serves as a guide, not as the final authority. Students might, for instance, reflect on their employment histories (their best and worst experiences at work) and develop possible strategies for organizational change.

Fourth, critical pedagogy makes learning experiences relevant by drawing meaningful connections between classroom content and students' lives both on and off the job. This can be done by basing discussion on student experiences and by tying activities to their problems and interests. At the same time, participants are involved in active citizenship, using their knowledge to serve others outside the educational setting.

Fifth, critical pedagogy makes topics problematic. Instead of filling participants with knowledge, instructors pose dilemmas that learners must solve. For example: How can employees gain more control over their working conditions? What role should technology play in organizational and societal change? Responding to these issues requires students to engage in 
critical, reflective thinking. Such thinking, which extends beyond technical matters to political, cultural, social and economic practices, can encourage students to change themselves, their organizations and the larger culture.

\section{Corporatism in the Traditional University}

In the new world of workplace learning, traditional universities no longer have a monopoly on knowledge, but have been relegated to one segment of the educational marketplace (Garrick and Clegg, 2000). Learners are educational consumers who can choose from a smorgasbord of educational offerings, and often make their selections on the basis of cost and convenience. Competition for students and tuition dollars can be fierce. The largest proprietary schools in the United States, which include the University of Phoenix, ITT Educational Services and DeVry University, among others, enroll approximately 700,000 students (Donoghue, 2008). Institutional technology (IT) certification programs enroll over 2 million US employees who might otherwise attend traditional colleges and universities, and draw as many students from abroad (Kirp, 2003).

Traditional institutions are responding to the new realities of the educational marketplace by adopting corporate practices. Like their corporate counterparts, modern universities:

Downsize and outsource. Universities are cutting costs in order to stay competitive. Programs that don't generate enough tuition dollars are reduced or eliminated, including such disciplines as history and philosophy that are at the heart of the traditional liberal arts curriculum (Giroux, 2006). The number of tenured faculty in the United States has declined even as enrollments have increased (Lafer, 2001). Adjuncts and graduate students, who earn substantially less and often do not receive insurance benefits, are replacing traditional full-time faculty members. Contingent faculty members now teach an estimated 50-70 percent of all credit hours at US colleges and universities and the salaries of full-time faculty have barely kept pace with inflation (Lafer, 2001; Wilson, 2008). Women and minorities make up a large percentage of the contingent faculty workforce (Entin, 2005).

Develop new revenue streams. Entrepreneurial universities (in addition to raising tuition) are quick to jump into the lucrative niches in the market, identifying profitable new programs and locations. Technology is a key tool for cutting costs and reaching new audiences. No longer bound by geography, a growing number of universities offer courses wherever the market may exist. These schools adopt a variety of nontraditional delivery systems, creating on-line courses, satellite campuses, and evening and weekend programs for working adults. A number of research institutions are also signing lucrative contracts with industry. These agreements allow corporations to patent and market drugs, cell lines and other products created in university laboratories (Bok, 2003; Washburn, 2005).

Focus on the customer. To keep tuition revenues high, the university/corporation must please the customer. Consumer demand determines what courses are offered; customer feedback determines which faculty members are retained (Poon, 2006). Traditional colleges and universities are now more vocationally oriented, increasingly 
focused on preparing graduates for jobs.

Corporatism puts the university at risk. Some of the disciplines that help develop self-reflective citizens may be eliminated. The widespread use of contingent teachers undermines traditional collegial faculty governance, which relies on peer decision-making (Muller et al., 1997). Temporary workers generally do not participate in committees and are denied the job security that would allow them to express unpopular opinions. A more hierarchical model has emerged where university presidents act like corporate CEOS and administrators make decisions with little discussion and debate (Muller et al., 1997; Giroux, 2006). Faculty collegiality has been replaced by a caste system where a few core tenured faculty members enjoy the benefits of traditional academic employment while the vast majority of instructors labor with little hope of advancement (Entin, 2005).

Traditional universities competing in the educational marketplace are tempted to put profit above quality. When program directors are evaluated based on the revenue they generate, they find it harder to turn down marginal applicants or to remove failing students. Keeping the customer happy may tempt professors to reduce academic rigor and fuel grade inflation. Decisions about which faculty to retain increasingly depends on high student evaluations rather than on the quality of course content. This is despite the fact that students, who are often new to a discipline, are not the best judges of what they need to learn and how material should be delivered. Driven by a customer mentality, many students appear minimally concerned about learning. Instead, they are more interested in earning high grades and earning additional credentials (Muller et al., 1997).

Finally, corporate research partnerships threaten academic freedom. Those researchers receiving industry funding may not be free to disseminate their findings to other members of the scientific community. Instead, the knowledge they generate belongs to the corporate sponsor. Information about failed medical procedures and ineffective drugs may never be released to the public (Washburn, 2005).

\section{Critical Response}

There is much to be said for operating in a businesslike manner. Good stewardship requires that resources be used carefully. Technology can enhance the learning process. Underserved markets should be provided with educational opportunities and the needs of students should be met. Yet, administrators and faculty at traditional universities ought to carefully consider which elements of corporate learning enhance the institution's mission and which detract from it. To maintain their heritage as centers of reflection, criticism, creation of knowledge and personal development, traditional universities will need to: (a) reduce the use of adjunct faculty and graduate student instructors; (b) resist the temptation to become knowledge factories serving industry; (c) focus on educational quality instead of profit; (d) be driven by mission and values rather than by customer demand; and (e) protect the rights of researchers to generate and disseminate information without corporate interference. 


\section{Exploitation of the Knowledge Worker}

In a movement intended to empower workers, the individual is often rendered powerless instead. The premise of lifelong learning is that the individual is deficient and needs to continuously acquire new skills and knowledge to keep up. As a result, "Workers' lives become a human resource development project" (Fenwick, 2001, p. 12). Those who don't actively pursue additional skills may be terminated. As noted earlier, training is designed to benefit the corporation not the individual. In fact, participating in workplace learning may work against the individual's interests and reinforce inequitable corporate policies. Employees often end up taking on greater responsibilities and putting in more hours on the job with no increase in pay. Balancing work with family responsibilities becomes more difficult as more time is devoted to job responsibilities.

The nature of knowledge work also calls for greater commitment than other types of labor. Knowledge workers have to commit their minds as well as their bodies to the organization (Forrester, 2002b). The service industry, one of the most rapidly expanding sectors of the global economy, also demands the emotional commitment of workers. Service employees engage in emotional labor by managing their emotions and emotional displays to create positive encounters with customers (Hochschild, 1983; Leidner, 1993).

The utilitarian focus of workplace learning does not speak to the deepest needs of employees. As organizations assume a greater role in societies, more workers seek meaningful tasks and relationships that serve significant purposes. This desire for meaning and connection is behind popular and academic interest in workplace spirituality. Duchon and Plowman (2005) define workplace spirituality as "the recognition that employees have an inner life that nourishes and is nourished by meaningful work that takes place in the context of community" (p. 809). Duchon, Plowman, and others argue that employees have spiritual needs-which involve their core identities and values - and are motivated by more than material rewards. Workers want their employment to be fulfilling and to serve the greater needs of society. At the same time, members desire significant connections with co-workers that nurture their inner lives.

Workplace learning that ignores the inner life of employees has a fragmenting effect because it speaks to only part of the individual's identity. Employees are increasingly interested in pursuing a vocation or life calling, not just in qualifying for a particular position (Rayburn, 1997). Determining a purpose in life means identifying one's unique skills, abilities, and desires, and applying those elements both on and off the job. Those who live out their vocations are more satisfied, are more committed to their organizations, and are better equipped for service to others (Johnson, 2007).

\section{Critical Response}

Adult educators should honor rather than diminish the worth of learner. They can do so by rejecting the notion that employees are deficient and by acknowledging instead that employees bring valuable knowledge and skills to the workplace and training setting. Human capital and human resources discourse ought to be replaced with language that acknowledges the strengths and importance of people. Some training content should promote individual development as 
well as corporate development. Those who upgrade their skills need to be rewarded, not burdened with additional responsibilities with no increase in pay. Corporations can encourage employees to maintain a balance between work and family responsibilities.

Organizations may also speak to the inner needs of workers by offering opportunities for spiritual development. In North America, meditation rooms and reflective gardens are found in a number of company headquarters and, according to one estimate, 4,000 chaplains are employed in secular organizations in the United States (Garcia-Zamor, 2003). While there are legal and ethical limitations to promoting particular beliefs in the workplace, spirit friendly corporations promote spiritual learning by studying spiritual materials, sponsoring spiritual discussion groups, and sending employees to workplace spirituality conferences (Johnson, 2009).

\section{Fostering Inequalities}

To date, workplace learning appears to be widening, not lessening, the gaps between the powerful and powerless, the haves and the have-nots. Executives, as we've seen, control access to workplace education as well as its content, and the needs of employees and unions are subjugated to corporate interests. The gulf between tenured faculty and contingent faculty at traditional universities is growing.

Members of marginalized groups are often denied the benefits of workplace learning (Butler, 1999; Proubert, 1999). This includes women, ethnic minorities, immigrants, the disabled, and others. Marginalized employees are less likely to be approved for training, and face prejudice, stereotypes, lack of mentoring and other barriers to career development. As a consequence, they earn less and have little chance of advancement. Even when women and other diverse groups are included in training programs, there is a good chance that their concerns will be ignored. For instance, success in many jobs depends on following the traditional male role model — the worker who defines himself by his job. This model does not reflect the reality that women often bear a far greater responsibility for children and other family members (Proubert, 1999).

The benefits of workplace learning are distributed unevenly within postindustrial economies. Those in the professionalmanagerial elite have the most access to education and workplace learning. Workers providing symbolic-analytic services centered on problem-identifying and problem-solving (e.g., research scientists, software engineers, public relations executives, lawyers, real estate developers, investment bankers) hold the most lucrative, highly valued positions in the US economy (Reich, 1991; Samper and Lakes, 1994). This portion of the workforce is highly educated (generally college graduates) and majority male. Women are typically gender segregated, relegated to in-person service occupations like nursing and childcare where they are required to be pleasant and nurturing. Routine production workers (often recent immigrants) receive only minimal training, generally in basic literacy skills.

Workplace learning also contributes to global inequality. Education is less available in developing countries, giving an ongoing advantage to wealthier nations. Large portions of the population in Africa, Asia, and South America work outside 
the formal economy and have no access to training at all. Instead of equipping nationals to prosper in the local economy, Western groups typically fund educational efforts in these nations that prepare workers for labor in the global economy. Graduates often do not find local positions but are hired to work in industrialized nations, leaving their countries of origin at a further disadvantage (Farrell and Fenwick, 2007). Multinationals also engage in "knowledge extraction," taking information from poor nations while giving little in return. For example, data produced in clinical drug trials in lessdeveloped nations goes back to company headquarters in Europe or North America. Weaker nations are given little support for their efforts to develop research facilities (Karim, 2000).

Cultural imperialism compounds global inequalities. Programs developed in the West generally promote individual development, which conflicts with the values of collectivist societies (Hoppe, 2004). Multinationals may offer training in English and ignore local educational practices. In other instances, workers must adopt Westernized behaviors to succeed. Consider the case of workers at Indian call centers that support US businesses, for example. They are taught to develop an American or British accent, learning how to pronounce letters like "o" or "r." They mask their identities, adopting a "Western persona" to fool clients into thinking they are talking to someone in the United States. They must take abuse from irate customers who are racially biased (Mirchandani and Maitra, 2007).

\section{Critical Response}

The inequalities fostered by workplace learning have to be addressed at both the organizational and societal level. Organizational leaders must create greater access for members of marginalized groups to training programs, mentoring initiatives, job sharing, and other efforts. They need to hire nontraditional instructors and provide nontraditional role models. At the same time, they ought to foster diverse organizational climates through diversity hiring and development initiatives, family friendly policies, flexible work arrangements, and diversity training, and by penalizing discriminatory behaviors and practices (racism, sexual harassment) on the job. Workplace educators should respect local values and practices when offering training programs in other cultural settings.

National and international leaders also have a role to play in promoting equality. They should encourage women and men to enter careers traditionally dominated by the other gender and equip workers in every sector of the workforce with skills that enable them to advance to better, higher paying positions. International organizations sponsoring educational efforts in developing nations ought to prepare citizens for local job openings. In addition, these sponsoring agencies should reach out to workers who labor outside the formal economy. Leaders in developed nations ought to limit the "poaching" of skilled individuals and knowledge extraction from developing countries.

\section{Conclusion}

Recognition that workplace learning has a shadow side serves as a reminder that "pedagogy is an inherently moral activity" (Myrick, 2004, p. 24). Workplace educators have ethical determinations to make about the nature and purpose of 
knowledge, competing values, balancing the needs of the individual and the organization, control over access to learning and curriculum, and their duty to either challenge or to support the social order. Further, they must make moral choices about the role of the traditional academy, their obligations to learners, and whether they have a responsibility to address inequalities.

Critics offer guidelines to educators faced with the ethical decisions described above. These tactics are rooted in concern for social justice, equity, quality, and inclusion. They promote democracy, education of the whole person (including the spiritual dimension) and learner empowerment, while fostering respect for individual dignity and diversity. Such guidelines will not be universally adopted. Proponents of workplace learning will likely disagree about the role of spirituality in the workplace, for instance, and the importance of educating the whole person. However, acknowledging the moral dimension of education on the job is an important first step. Only then can advocates begin to address the potential harm posed by learning situated at work, bringing the practice of workplace learning more in line with the positive rhetoric it generates.

Craig E.Johnson

\section{References}

Aronowitz, S.(1990)‘The New Labor Education: A Return to Ideology’, in S.H.London,E.R.Tarr and J.F.Wilson (eds), The Re-education of the American Working Class. Westport, CT: Greenwood Press. pp. 21-33.

Bok, D.(2003)Universities in the Marketplace: The Commercialization of Higher Education. Princeton, NJ: Princeton University.

Bouchard, P.(1998)'Training and Work: Myths about Human Capital', in S.M.Scott,B.Spencer and A.M.Thomas (eds), Learning for Life: Canadian Readings in Adult Education. Toronto: Thompson. pp. 128-140.

Boud, D. and Garrick, J.(1999)'Understandings of Workplace Learning', in D.Boud and J.Garrick (eds), Understanding Learning at Work. London: Routledge, pp. 1-11.

Brown, P.C.'Liberal Education for Leadership', Liberal Education, 80(2): 44-48. (1994)

Butler, E.(1999) ‘Technologising Equity: The Politics and Practices of Work-Related Learning', in D.Boudand J.Garrick (eds), Understanding Learning at Work, London: Routledge. pp. 132-150.

Butler, E.'Knowing "Now", Learning Futures: The Politics and Knowledge Practices of Vocational Education and Training', International Journal of Lifelong Education, 19(4): 322-

341. (2000)http://dx.doi.org.georgefox.idm.oclc.org/10.1080/02601370050110383

Caldwell, P.(2000)'Adult Learning and the Workplace', in H.Rainbird (ed.), Training in the Workplace: Critical Perspectives on Learning at Work. New York: St. Martin's Press. pp. 244-263.

Dewey, J.(1916)Democracy and Education. New York: Free Press.

Donoghue, F.(2008)The Last Professors: The Corporate University and the Fate of the Humanities. New York: Fordham University Press.

Drucker, P.(2001)The Essential Drucker. New York: HarperBusiness.

Duchon, D. and Plowman, D.A. 'Nurturing the Spirit at Work: Impact on Work Unit Performance', Leadership Quarterly, 16(5): 807-833. (2005)http://dx.doi.org.georgefox.idm.oclc.org/10.1016/j.leaqua.2005.07.008 
Entin, J.'Contingent Teaching, Corporate Universities, and the Academic Labor Movement', Radical Teacher, issue 73: 26-32. (2005)

Farrell, L. and Fenwick, T.(2007)‘Educating a Global Workforce?', in L.Farrell and T.Fenwick (eds), World Yearbook of Education 2007. Educating the Global Workforce: Knowledge, Knowledge Work and Knowledge Workers. London: Routledge. pp. 13-26.

Fenwick, T.(1998)'Questioning the Concept of the Learning Organization', in S.M.Scott,B.Spencer and A.M.Thomas (eds), Learning for Life: Canadian Readings in Adult Education. Toronto: Thompson. pp. 140-152.

Fenwick, T.'Tides of Change: New Themes and Questions in Workplace Learning', New Directions for Adult and Continuing Education, 92, Winter: 3-17. (2001)

Forrester, K.(2002a)'Unions and Workplace Learning: The British Experience', in B.Spencer (ed.), Unions and Learning in a Global Economy: International and Comparative Perspectives, Toronto: Thompson. pp. 138-148.

Forrester, K.'Work-Related Learning and the Struggle for Employee Commitment', Studies in the Education of Adults, vol. 34(1): 42-55. (2002b)

Garcia-Zamor, J.C.'Workplace Spirituality and Organizational Performance', Public Administration Review, 63(3): 355363. (2003)http://dx.doi.org.georgefox.idm.oclc.org/10.1111/1540-6210.00295

Garrick, J. and Clegg, S.(2000)‘Organizational Gothic: Transfusing Vitality and Transforming the Corporate Body through Work-Based Learning', in C.Symes and J.Mclntyre (eds), Working Knowledge: The New Vocationalism and Higher Education. Buckingham, UK: The Society for Research into Higher Education. pp. 153-171.

Giroux, H.A.(2006)'Higher Education under Siege: Implications for Public Intellectuals', Thought and Action, Fall: 63-78.

Gregson, J.A.(1994)'From Critical Theory to Critical Practice: Transformative Vocational Classrooms', in R.D.Lakes (ed.), Critical Education for Work: Multidisciplinary approaches. Norwood, NJ: Ablex. pp. 161-169.

Heyes, J.(1999)'Workplace Industrial Relations and Training', in H.Rainbird (ed.), Training in the Workplace: Critical Perspectives on Learning at Work. New York: St. Martin's Press. pp. 153-171.

Hochschild, A.R.(1983)The Managed Heart: Commercialization of Human Feeling, Berkeley: University of California Press.

Hoppe, M.H.(2004)'Cross-Cultural Issues in the Development of Leaders’, in C.D.McCauley and E.Van Velsor (eds), The Center for Creative Leadership Handbook of Leadership Development, San Francisco: Jossey Bass. pp. 331-360.

Houston, G.R.'Bury the Liberal vs. Professional Arts Debate', Education, 117(1): 12-16. (1996)

Hundley, S.P.'Corporate Universities: Collaboration, not Competition', Assessment Update, 14(1): SeptemberOctober: 1-2,14-15. (2002)

Jarvis, P.(2001)Universities and Corporate Universities: The Higher Learning Industry in Global Society. London: Kogan Page.

Johnson, C.E.(2007)Ethics in the Workplace: Tools and Tactics for Organizational Transformation, ThousandOaks, CA: Sage.

Johnson, C.E.(2009)Meeting the Ethical Challenges of Leadership: Casting Light or Shadow,

(3rd edn)

. Thousand Oaks, CA: Sage.

Karim, A.(2000)'Globalization, Ethics, and AIDS Vaccines', Science, 23 June, 21-29.

Kirp, D.L.(2003)Shakespeare, Einstein, and the Bottom Line: The Marketing of Higher Education. Cambridge, 
MA: Harvard University Press.

Lafer.G.(2001)‘Graduate Student Unions Fight the Corporate University’, Dissent, Fall: 63-70.

Leidner, R.(1993)Fast Food, Fast Talk: Service Work and the Routinization of Everyday Life. Berkeley: University of California Press.

Mantsios, G.(1990)'Worker Education: Developing an Approach to Worker Empowerment', in S.H.London,E.R.Tarr and J.F.Wilson (eds), The Re-education of the American Working Class. Westport, CT: Greenwood Press. pp. 35-49.

Meister, J.C.(1998)Corporate Universities: Lessons in Building a World-Class Work Force.

(Rev. edn)

. New York: McGraw-Hill.

Mirchandani, K. and Maitru, S.(2007)'Learning Imperialism through Training In Transnational Call Centres', in L.Farrell and T.Fenwick (eds), World Yearbook of Education 2007. Educating the Global Workforce: Knowledge, Knowledge Work and Knowledge Workers. London: Routledge. pp. 154-164.

Muller, H.J., Porter, J. and Rehder, R.R.'The Invasion of the Mind Snatchers: The Business of Business Education', Journal of Education for Business, 72(3): 164-

169. (1997)http://dx.doi.org.georgefox.idm.oclc.org/10.1080/08832323.1997.10116848

Myrick, F.'Pedagogical Integrity in the Knowledge Economy', Nursing Philosophy, 5(1): 23-

29. (2004)http://dx.doi.org.georgefox.idm.oclc.org/10.1111/j.1466-769X.2004.00164.x

Poon, T.S.'The Commodification of Higher Education: Implications for Academic Work and Employment', International Journal of Employment Studies, 14(1): 81-104. (2006)

Prince, C. and Beaver, G.'Facilitating Organizational Change: The Role and Development of the Corporate University', Strategic Change, 10(4): 189-122. (2001)http://dx.doi.org.georgefox.idm.oclc.org/10.1002/jsc.541

Proubert, B.(1999)‘Gendered Workers and Gendered Work: Implications for Women's Learning', in D.Boud and J.Garrick (eds), Understanding Learning at Work. London: Routledge. pp. 98-116.

Rayburn, C.A.(1997)'Vocation as Calling', in D.P.Bloch and L.J.Richmond (eds), Connections Between Spirit and Work in Career Development. Palo Alto, CA: Davies-Black. pp. 162-183.

Reich, R.B.(1991)The Work of Nations: Preparing Ourselves for 21st Century Capitalism. New York: Knopf.

Samper, M.D. and Lakes, R.D.(1994)'Work Education for the Next Century: Beyond Skills Training', in R.D.Lakes (ed.), Critical Education for Work: MultidisciplinaryApproaches, Norwood, NJ: Ablex. 95-107.

Spencer, B.(2002)'Preface', in B.Spencer (ed.),Unions and Learning in the Global Economy: International and Comparative Perspectives. Toronto: Thompson. pp. 11-13.

Starbucks(2008)'Mission Statement', viewed September 10, 2008, <http://starbucks.com/aboutus/environment.asp.

Sutherland, J. and Rainbird, H.(1999)'Unions and Workplace Learning: Conflict or Cooperation with the Employer?’' in H.Rainbird (ed.), Training in the Workplace: Critical Perspectives on Learning at Work. New York: St. Martin's Press. pp. 189-209.

Symes, C. and McIntyre, J.(2000)'Working Knowledge: An Introduction to the New Business of Learning', in C.Symes and J.McIntyre (eds), Working Knowledge: The New Vocationalism and Higher Education. Buckingham, UK: Open University Press. pp. 1-13.

Taylor, J.(2007)'From Union Education to Workers' Education: Workers Learning How to Confront Twenty-First-Century Capitalism', in L.Farrell and T.Fenwick (eds), World Yearbook of Education 2007. Educating the Global Workforce: Knowledge, Knowledge Work and Knowledge Workers. London: Routledge. pp. 65-75. 
Useem, M.(1989)Liberal Education and the Corporation: The Hiring and Advancement of College Graduates. New York: Aldine de Gruyer.

Washburn, J.(2005)University, Inc.: The Corporate Corruption of American Higher Education. New York: Basic Books.

Wilson, R.'College Too Pricey? Don't Blame Faculty Pay’, The Chronicle of Higher Education, vol. LV, no. 11,7 November. pp. A1, A10. (2008) 